\title{
Analysis on Traditional Commercial Street Quality with a Neighborhood Communication Perspective — A Case of Rue de Marchienne, Belgium
}

\author{
Wen-Yi Fan ${ }^{1, ~ *, ~ N o e l ~ B . ~ S a l a z a r ² ~}$ \\ ${ }^{1}$ Department of Tourism, International Business School, Zhejiang International Studies University, Hangzhou, China \\ ${ }^{2}$ Faculty of Social Sciences, University of Leuven, Leuven, Belgium
}

Email address:

fanwenyi1983@sina.com (Wen-Yi Fan), Noel.Salazar@soc.kuleuven.be (N. B. Salazar)

*Corresponding author

\section{To cite this article:}

Wen-Yi Fan, Noel B. Salazar. Analysis on Traditional Commercial Street Quality with a Neighborhood Communication Perspective - A Case of Rue de Marchienne, Belgium. Science Journal of Business and Management. Vol. 4, No. 5, 2016, pp. 181-186. doi: $10.11648 /$ j.sjbm.20160405.16

Received: October 13, 2016; Accepted: November 4, 2016; Published: November 5, 2016

\begin{abstract}
Traditional commercial street exists and functions as an important public space in city. Existing literatures have highlighted street quality at different aspects but still call for more case study and regional research. This paper is on improving the quality of traditional commercial street. A case study of a typical traditional commercial street Rue de Marchienne, Belgium is analyzed based on fieldwork. The study tries to investigate the problems in urban design that hamper Rue de Marchienne from a high quality street with social interactions. Six specific evaluation measures are applied, which aims to further identify those problems by mapping and inter-discipline methodologies from urbanism, geography as well as economy. The findings indicate several strategies and generate specific improvements for urban planners and designers for Rue de Marchienne.
\end{abstract}

Keywords: Traditional Commercial Street, Rue De Marchienne, Neighborhood Communication, Evaluation Measures

\section{Introduction}

Commercial street is a kind of important public space in urban tissue where people often gather for shopping, trading and social interactions. Street is the basic framework and important exterior space of a city [1], as well as a decisive element showing a city's characteristics. Traditional commercial street can be defined as major street with commercial activities for a long time [2]. This paper studies on a specific traditional commercial street_Rue de Marchienne, Charleroi, Belgium. We did fieldwork in Rue de Marchienne in earlier 2015 for redesigning a social housing project Allée Verte entrusted by the Charleroi Municipal Government and looked closely into this street. In a post-industrial era, the decline of the former industrial city Charleroi urgently calls for rejuvenation for its city. As a place for shopping, socializing and civic life, while Rue de Marchienne is losing its centrality for lack of social interactions and economic vitality. This paper is on improving the quality of traditional commercial street. In this paper, six specific evaluation measures are applied, which aim to further identify those problems and point to enhance the street's neighborhood communication by mapping and inter-discipline methodologies from urbanism, geography as well as economy.

\section{Literature Review}

Existing references emphasize street quality at different aspects. Addressing on the association between street design and human interaction, Jan Gehl illustrates only if outdoor space is of high quality, optional activity and social activity would take place [3]. Different space environment will create different neighborhood, feelings of security and fear of crime as well as different social interaction and perception [4 6]. A street should be able to increase public activities. The vitality of city street is rooted in the safety and the diversity [7, 8]. Yoshinobu Ashihara explains street is an exterior space formed by architecture's inner order [9]. Exterior space is more meaningful than the natural space and has close 
association with human behavior. In street morphology, the three key components are street network, the open spaces and the buildings [10]. Street should provide people a place with traffic, activity, interaction and become an element to support the image of city [11]. Traditional commercial street usually formed before industrial era and a residential-commercial mixed street at beginning. With the development for years in industrial era, shops and office apartments gradually crammed into the street while residents moved out. This kind of traditional commercial street is usually located in the downtown center or tourist center. It is not hard to find such streets, such as those commercial streets around Grande Place in Brussels. More often, traditional commercial streets keep the way as commercial and residential mixed use. This kind of street is pedestrian friendly [12].

\section{Evolution of Rue de Marchienne and Facts}

Rue de Marchienne is a north-south street in Jumet, Charleroi which is located in the province of Hainaut, Belgium. The street's history is long. On the map of Charleroi in 1777, its general shape had formed. Some parts of it at that time were similar to today's. The history of this street is even earlier than that of the Church, Eglise de Jumet Gohyssart, on Place du Ballon in the center of Jumet. In the late 19th Century, human settlements were built up along the street, especially the section near the church. Other parts were mostly surrounded by large greenery and forest. When social housing projects such as Cité des Acacias, Cité Peetermans and Allée Verte were built up between 1960's and 1970's, more residents were settled there along the street while large greenery retreated. The Centre Funéraire Charles (the cemetery) has taken up a large part of green area since 1930's not far from the road.

Zooming into a street network, Rue Puissant and Rue de Dampremy are the two earliest streets with intersections with Rue de Marchienne. Before the highway Route du Centre was built up, Allée Verte and Rue Puissant were articulated and met with Rue de Marchienne. When the highway was finally constructed in 1970's, the road Allée Verte was repaired up to the north. The two are separated on each side of Rue de Marchienne and become two different roads with each having a crossing with Rue de Marchienne from then on.

Rue de Marchienne today is a 600-meter long street with residential houses and shops along the street. The road starts at the south on Place du Ballon, ending at the crossing point with Rue Pierre Bauwens, Rue des Coteaux and Rue de Jumet. Average street width is of 15 meters. Most buildings on two sides of the street are one or two stories with each floor height around 3 meters. The topography can be found in Figure 1 with elevation from 158-meter to 164-meter above the sea level. Now when searching by the name of Rue de Marchienne on search engine such as Google, the popping-up web links most probably the introductions of shops in the street. Rue de Marchienne is one of the earliest streets with residents in
Jumet, commercial services are there serving the locals. There is relatively dense network of neighborhoods shops. At the same time, it is in close proximity to transportation nodes and near local historic town center__Place du Ballon.

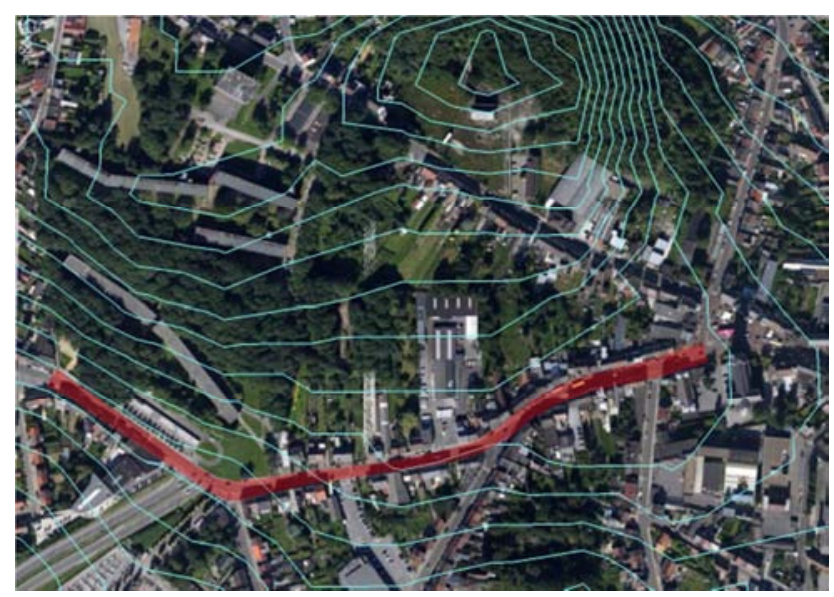

Figure 1. Location and topography of Rue de Marchienne,Belgium.

\section{A Segmented Rue de Marchienne}

There are important institutions on Rue de Marchienne for the locals, such as Charleroi center s.p.r.l (automobile center), Carrefour supermarket, Raposo (furniture equipment manufacturing factory), schools and the church. Along the street, parking boards are here and there telling people where stop car. It is also a main carriageway of the area. This street meets the highway Route du Centre which links Jumet area with other parts of Charleroi city. Public transport goes through the street then goes further through the palace to other parts of Jumet. An image of 3D model of Rue de Marchienne illustrates the urban tissues today (Figure 2). Rue de Marchienne has some obvious problems.

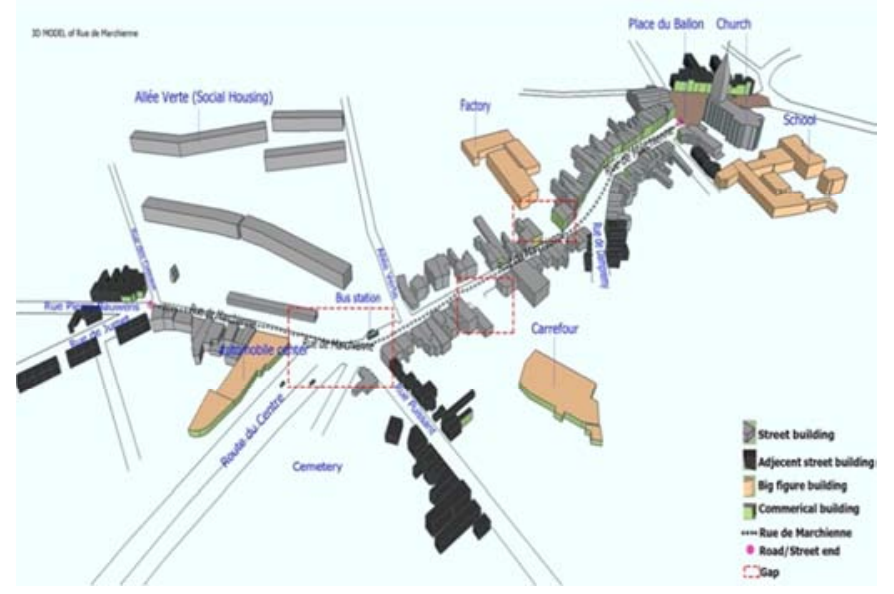

Figure 2. 3D Model of Rue de Marchienne (By Author).

It is not hard to find the Rue de Marchienne lacks continuity. The intersection with highway Route du Centre in the middle of the street, has poor attachment with its surrounding urban tissues. People come from highway by car with a high speed then turn right or left leaving away quickly. Pedestrians from 
nearby neighborhoods seldom stay here except quickly walking by. The cemetery and social housing Allée Verte are located here face by face on each side of the street. A negative point is obliviously to see. This condition makes the whole road look like three segmented different roads. Flows and activities in the street have very big difference according to on-site research. The section from the entrance of Place du Ballon to the intersection with Rue de Dampremy is more often used and people like to walk through it on foot.

By contrast, from the intersection with Rue Puissant to the other end people prefer to drive. In his book The Image of the City, Lynch once summarizes the four characteristics of a path He points out that a path should be with identifiability, continuity, directionality and metrizability [13]. As of a street like Rue de Marchienne, its problems are clear. It is one important local street in terms of articulation, not only for traffic but with social and economic cohesion since its beginning. While it loses attachment with its neighborhoods as an identifiable complete street. Some part is more often used by people, while some part is only a traffic point with negative social function. This paper then tries to investigate the traditional commercial street from the angle of enhancing neighborhood communication and social interaction.

\section{Six Specific Evaluation Measures}

With relevant literatures, this paper applies six specific evaluation measures to analyze street pleasantness, safety and functionality on Rue de Marchienne. These six proposed evaluation measures are based upon aesthetics, safety, and ease of movement which aim to improve street quality. Rue de Marchienne entails much more than "commuting" function, it also has social and economic functions to the neighborhoods. This old commercial corridor should have a potential to boost the willingness of the local neighborhood communication.

\subsection{Enclosure}

High quality of enclosure makes eyes'attention focused on the street rather than the setback spaces between, behind, or in front of street buildings [14]. Well enclosure also has positive impacts on safety as well as aesthetics. The sense of street enclosure is defined by the building that edge the street.

Referring to the enclosure in Rue de Marchienne, gaps between buildings are in some sections of the street, especially at the intersection space with the high way. Figure 2 also shows where some big "gaps" are in the street. Moreover, no street trees are there along the street in front those buildings filling into the gaps. These wide-open, unconstrained gaps support high traffic speed but create negative conditions for people stay. With a perceived danger, people will not stay at the place long for further social interactions, such as chatting freely with an acquaintance or playing around with children and dogs. The street part near the Place du Ballon is with good street enclosure quality. Building there is next to each other with a shared side wall and billboards fill and seal the gaps between buildings. The enclosure conveys a feeling of narrowness and safety for people.

\subsection{Articulation}

Building articulation refers to the many street frontage design elements that help create a streetscape of interest and social interactions. The appropriate scale for articulation is often a function of the size of the building and the adjacent public spaces. Large buildings like social housing Allée Verte and the modern automobile center make the street not only have big space gaps, but lack of uniformly continuous architecture style. Inappropriate scale for articulation leads to a left-over space in the street. It is hard for people to define Rue de Marchienne as a complete street. Carrefour supermarket on the side of the road makes street building articulation suddenly disappear once again. The ground floor of building is commonly rented out as shops while the upper floors are still residential. This condition makes one building façade partly occupied by storefront and partly opened as the entrance door for residents. Furthermore, some buildings with a front garage are directly facing the street. Garage door brushed in a light color makes the building articulation visually fragmented.

\subsection{Open Space}

Open space is a key element of street morphology. It refers to the public space in front of street buildings. Such public places as plazas, parks courtyards, and playgrounds draw people's attention to the unique qualities of a particular area of the street as well as attracting people with related social interactions. Putting yourself in the role of somebody using the open space of Rue de Marchienne, you are not easy to find a place to take a rest. The only choice is to walk straight further to the Place du Ballon where there are a few benches for sit. Complexity of spaces in Rue de Marchienne is few. Figure 3 shows a triangle shaped open space formed by the intersection among Rue de Marchienne, Rue de Dampremy and Rue de Marchienne. This area is in the middle section of the street with a potential to be an interesting public space for people gathering and stay. While it is only used as a traffic node and is dangerous and dull for the locals. The lack of people leads to the low vitality of local small and medium street economy. Rue de Marchienne doesn't have enough civic activities as a local commercial corridor for its scarce of open space.

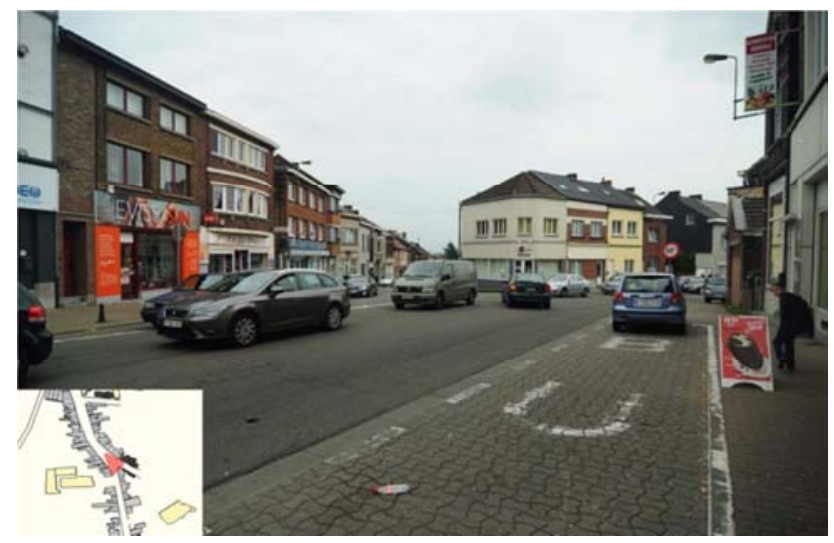

Figure 3. A triangle shaped open space in the middle part of Rue de Marchienne. 


\subsection{Buffer in the Street}

A street with high quality encourages walking by, slow traffic and enhancing pedestrian safety. Figure 4 shows the cross-section of Rue de Marchienne. In the 15-meter wide street, a 2.5-meter parking lane and 2-meter pedestrian lane are on each lateral side of the street. The design of this type cross-section is seen as a buffer to encourage all flows to slow down. While it looks like a paradox for the parallel parking buffer here. The problem is that when car stops at the parking lane, it cuts off the pedestrian's visual interest. Pedestrian on each side of the road can't keep eyes on the street. This buffer doesn't support a safe, friendly pedestrian environment.

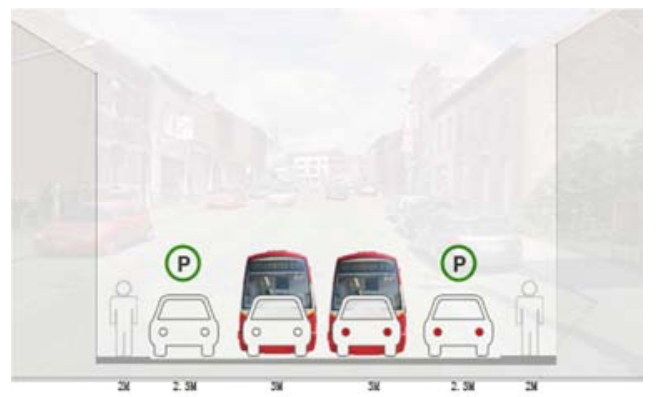

Figure 4. Street cross-section of Rue de Marchienne (By Author).

\subsection{Visual Interest}

The greatest streets are ones that support the movement of pedestrians by extending a street wall with visual interest. An easy visual transition between commercial street exterior space and building interior space can be created by the use of storefront glass windows, outdoor commercial activities and sidewalk stalls. Shops along Rue de Marchienne with commercial advertising posters on the storefront window attract walk-bys with the opportunity coming in for shopping. These posters on the storefront glass window don't be changed to new ones for several months. The outdated posters turn into a barrier of visual interest then. As mentioned before in this paper, cars stopped in front of buildings also become an impermeable barrier for people to see through the window glass (Figure 5).

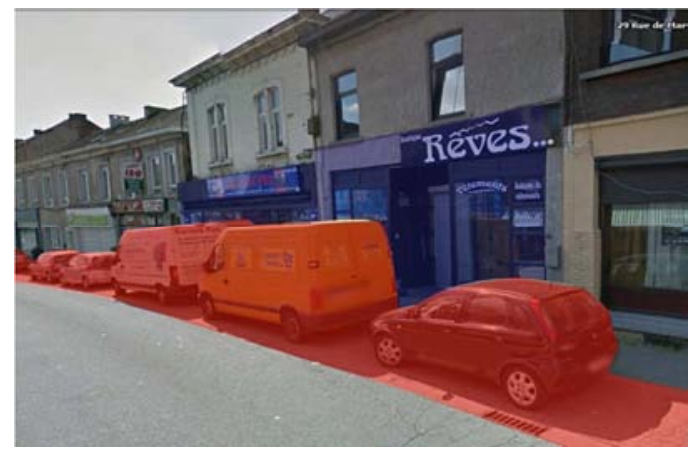

Figure 5. Parking lane on Rue de Marchienne (By Author).

\subsection{Light and Commercial Format}

One of the critical problems for Rue de Marchienne is that there are not enough street lights. In proximity with the cemetery and highway, negative points there are not good for social interactions. When dark is coming, there is few people walking into Rue de Marchienne expect cars driving though. The light facilities along the street have considerable implications for community safety by preventing people from criminal activities and traffic accident. Commercial formats here are mostly day-time (table 1). Gathering places during off-work leisure time and night are far from enough. People are not willing to walk through Rue de Marchienne to reach those pubs on the Place du Ballon for they don't feel safe in the night. If there is not enough street light, a large part of the street is seldom to attract people during night, especially the young generation.

Table 1. Commercial Formats in Rue de Marchienne.

\begin{tabular}{llll}
\hline Commercial Format & Number & Location & Business Hour \\
\hline Grocery store & 19 & $\begin{array}{l}\text { North and } \\
\text { Middle Sections }\end{array}$ & Day Hour \\
$\begin{array}{l}\text { Automobile service } \\
\text { Boutique }\end{array}$ & 6 & $\begin{array}{l}\text { South Section } \\
\text { Middle Section }\end{array}$ & $\begin{array}{l}\text { Day Hour } \\
\text { Day Hour }\end{array}$ \\
$\begin{array}{l}\text { Bookstore \& } \\
\text { printing service }\end{array}$ & 2 & Middle Section & Day Hour \\
Electronics \& & & North and & Middle Sections \\
audio-video shop & 3 & Day Hour \\
$\begin{array}{l}\text { Chain store } \\
\text { Super market }\end{array}$ & 1 & $\begin{array}{l}\text { Middle Section } \\
\text { North and }\end{array}$ & Day Hour \\
Pharmacy & 1 & Middle Sections & Day Hour \\
Cosmetics shop & 2 & $\begin{array}{l}\text { Middle Section } \\
\text { North Section }\end{array}$ & Day Hour \\
Bar and club & 2 & $\begin{array}{l}\text { Diddle Section } \\
\text { Financial service }\end{array}$ & Day Hour \\
Office apartment & 5 & $\begin{array}{l}\text { North and } \\
\text { Middle Sections } \\
\text { Middle Section }\end{array}$ & Day Hour \\
$\begin{array}{l}\text { Laundry } \\
\text { Specialty store } \\
\text { furniture) }\end{array}$ & 1 & Day \&Night \\
\hline
\end{tabular}
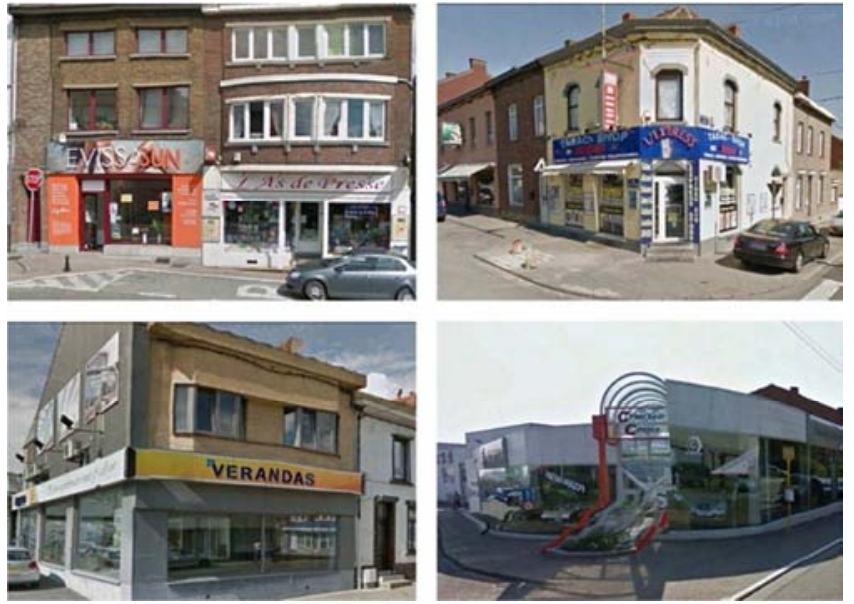

Figure 6. Commercial formats in Rue de Marchienne (By Authors).

\subsection{Discussions}

Good streets and spaces are created by enclosing them with buildings and a strong landscaping scheme. Buildings should face the street with little or no setback. The street enclosure quality can be improved in more economical ways if new 
building intervention is not the first choice. Literature also indicates the street tree is important. Jacobs contends that: "It is the intervening trees as much as or more than buildings that strengthen or provide definition. That is one of their purposes and speaks to the necessity of their closeness and fullness" [15]. Community collective greening activities, such as street beautification and tree planting can help gather locals to join in social interactions.

Improvement of building articulation is best illustrated through more street frontage design elements, both horizontal and vertical. Stylish landscape sculpture works and decorative landscape planters can be put into the "gaps" along the street, which the inspirations are consulted from neighborhood. Façade with small unit is more effective to define Rue de Marchienne as a complete street.

Projects of public spaces are needed to provide the street with more public realms to encourage collective social activities. A mini park in the middle section of the street dotted with flowers and more benches for rest can slow down traffic flows and encourage people for stay. Weekend fair market selling local organic food and vegetables may also a good idea to attract people join into the street. Pop up public space such as open beer garden or café brings colorful vibrant play spaces to neighborhood, making the street more charming to younger generation.

A pedestrian priority street with "buffer lane" between the sidewalk and travel lanes consisting of extensive landscaping is good for people communicating. In order to solve the paradox problem of the parallel parking buffer in Rue de Marchienne, it is suggested to remove the parking lane and replace it with a bicycle lane and a line of shaded trees. This can also enhance the pedestrian's visual interest on the road and encourage slow traffic. As a street enhancing all people's interaction, the overall physical condition of sidewalks and streets should profoundly take into consideration.

Instead of window posters, demountable or hanging commercial shop signs would be a better choice. Street murals can add more visual interest to a neighborhood street. Residents come together with an ideal to paint a mural along the streetscape with a variety in setbacks and projections. The design on the road way can be a way to promote a sense of community in the neighborhood. This also can help calm traffic and enhance safety and security for pedestrians in Rue de Marchienne.

Street lighting is a basic need and essential for public safety and security. In Rue de Marchienne, more streetlights should be installed to improve lighting quality, quality of life and public safety. A diverse commercial formats can add the street commercial vitality all the time around. Such as mini cinema, off-work fitness center should be considered to intervene to promote night life quality for local people.

\section{Main Conclusion}

Street is a linear corridor connecting surrounding urban tissue. This paper looks closely into a traditional commercial street Rue de Marchienne at Charleroi, Belgium. As a place to gather locals for a long time dating from history, the street should have been an arena for shopping, socializing and civic life. While the reality is that it seems to be a failure to attract neighborhood interactions. Some critical problems mentioned in this study explain Rue de Marchienne is with low street quality. The six evaluation measures proposed in this paper identify street problems on Rue de Marchienne and contribute to a future positive street quality on improving neighborhood communication. The use of these evaluation measures in analysis also help generate specific improvements in the future for urban planners and designers.

\section{Acknowledgements}

This research work was supported by The National Natural Science Foundation of China Project "Study on Commercial Forms Differentiation Mechanism and its Management Model Construction at Center Area of Typical Tourism Small Town in China New-type Urbanization---Based on the Study in Hangjiahu Area" under Grant No. 71403252 ; Natural Science Foundation of Zhejiang Province, China Project "Commercial Forms Differentiation Mechanism and its Management Model Construction at Tourism Villages and Towns---Based on Zhejiang Province" under Grant No. LQ13G020009; China Scholarship Council Project under Grant No. 201308330257.

\section{References}

[1] Moughtin, C. (2003). Urban Design: Street and Square (3rd ed.). Oxford: Architectural Press.

[2] Loukaitou-Sideris, A. (1997). Inner-city commercial strips: Evolution, decay-retrofit?. Town Planning Review, 68(1), 1-29.

[3] Gehl, J. (2001). Life Between Buildings: Using Public Space (5th ed.). Copenhagen: Danish Architectural Press.

[4] Mõttus, R., Gale, C. R., \& Starr, J. M., et al. (2012). 'On the street where you live': Neighborhood deprivation and quality of life among community-dwelling older people in Edinburgh, Scotland. Social Science \& Medicine, 74(9), 1368-1374.

[5] Mehta, V. (2009). Look closely and you will see, listen carefully and you will hear: Urban design and social interaction on streets. Journal of Urban Design, 14(1):29-64.

[6] Thompson, C. W., Curl, A., \& Aspinall, P., et al. (2014). Do changes to the local street environment alter behaviour and quality of life of older adults? The 'DIY streets' intervention. British Journal of Sports Medicine, 48(13), 1059-1065.

[7] Zhou, B. \& Gong, R. (2010). Renew old commercial street in the perspective of urban vitality. Journal of Hunan City University (Natural Science), 19(2), 33-37.

[8] Cohen, L. (2007). Buying into downtown revival: the centrality of retail to postwar urban renewal in American cities. The ANNALS of the American Academy of Politicaland Social Science, 82-95.

[9] Yoshinobu, A. (2006). The Aesthetic Townscape (P. T. Yin, Trans.). Tianjin, China: Baihua Literature \& Art Publishing House. 
[10] Agryzkov, T., Oliver, J. L., \& Tortosa, L., et al. (2014). Analyzing the commercial activities of a street network by ranking their nodes: a case study in Murcia, Spain. International Journal of Geographical Information Science, 28(3), 479-495.

[11] Lynch, K. (1995). Reconsidering the Image of the City, in City Sense and City Design. Cambridge, Mass: The MIT Press.

[12] Koohsari, M. J., Karakiewicz, J. A., \& Kaczynski, A. T. (2013). Public open space and walking. Environment \& Behavior, 45(6),706-736.
[13] Lynch, K. (1960). The Image of the City. Cambridge, MA: Technology Press.

[14] Jaskiewicz, F. (2000). Pedestrian level of service based on trip quality. Transportation Research Circular E-C019, TRB, Washington, DC: National Research Council.

[15] Jacobs, A. B. (1993). Great Streets. Cambridge, MA: MIT Press. 